\title{
ResearchOnline@JCU
}

This is the Accepted Version of a paper published in the journal School Leadership and Management:

Hariri, Hasan, Monypenny, Richard, and Prideaux, Murray

(2014) Leadership styles and decision-making styles in an Indonesian school context. School Leadership and Management, 34 (3). pp. 284-298.

http://dx.doi.org/10.1080/13632434.2013.849678 


\section{Leadership styles and decision-making styles in an Indonesian}

\section{school context}

A paper accepted for publication by School Leadership \& Management (2010 ERA ranking A) Impact factor not found on 5 September 2013

Hasan Hariri, Richard Monypenny \& Murray Prideaux

School of Business, James Cook University, Townsville, QLD,

Australia

Corresponding author Richard.Monypenny @jcu.edu.au

\section{Acknowledgements}

This study was funded by Directorate General of Higher Education, Ministry of Education and Culture, the Republic of Indonesia, and James Cook University, Australia.

Our special thanks go to the editors and the anonymous reviewers for their constructive feedback on this paper.

We would also like to thank our colleagues for commenting on earlier drafts and Sharon Read for copyediting.

\section{Notes on contributors}

Hasan Hariri is a recent $\mathrm{PhD}$ graduate in Management, School of Business, James Cook University, Australia, and is currently working at University of Lampung (Unila), Bandar Lampung, Indonesia. His current research interests include leadership, school leadership and management, decision-making and job satisfaction.

Richard Monypenny is Adjunct Associate Professor in Economics, School of Business, James Cook University, Australia. His current research interests include successful regional development, systems thinking, small group dynamics, collaboration and facilitating change.

Murray Prideaux is a Senior Lecturer in Management, School of Business, James Cook University, Australia.

\section{Abstract}

School leadership has been well researched in developed countries. However, in Asia, particularly in Indonesia, school leadership has not been well explored. Using survey data from a sample of 475 teachers in six Lampung school districts, this paper examines the relationships between school principal leadership styles and school principal decision-making styles in an Indonesian school context. Findings are that most of the relationships between school principal leadership styles and school principal decision-making styles are significant. These findings suggest that teachers perceive that principals should exhibit much more transformational leadership style and rational decision-making style but avoid laissez-faire leadership style and avoidant decision-making style. 
Keywords: leadership; decision-making; schools; principals; teachers; Indonesia

\section{Introduction}

The success of an organisation, like a school, largely depends on the quality of the decisions made by their leaders (Eberlin and Tatum 2008; Robbins et al. 2009). Thus, transformational school principals usually lead schools in democratic and participative ways and involve more teachers in the decision-making because these leaders can engage in collaborative leadership and decision-making (Petzko et al. 2002, 4 in Sanzo, Sherman, and Clayton 2011, 33). Effective principals involve teachers in decision-making (Barnett and McCormick 2003, 64; Pashiardis 1993, 8; Williams 2006) and leadership styles are largely related to decision-making styles Kao and Kao (2007, 71). Transformational, transactional and laissez-faire leadership styles tend to be related to particular decision-making styles (Tatum et al. 2003, 1012).

The interaction between the various drivers of school leadership and decision-making have been, and will continue to be, an important cornerstone of many governments' school growth plans, see for example: 'Classroom and school factors related to student achievement' (Teodorovic 2011); and 'Using school performance feedback' (Verhaeghe et al. 2010).

This paper is one of several about school leadership in schools in Lampung Province, Indonesia. This paper is specifically about the responses from a sample of teachers with regard to principal leadership styles and principal decision-making styles, to address the following three research questions:

What are the relationships between principal leadership styles?

What are the relationships between principal decision-making styles?

What are the relationships between principal leadership styles and principal decision-making styles?

This paper uses survey data from a sample of 475 teachers in six Lampung school districts.

This paper is in four parts. First, it provides a literature review on school leadership, leadership styles, decision-making styles and on the Indonesian context. Second, it describes the instruments, data collection procedure, and data analysis. Third, it presents and discusses the findings. Finally, it outlines the conclusions and implications applying to principals.

\section{Literature review}

\section{School leadership}

School leadership is important for school effectiveness, because principals have significant influence upon the success of schools (Gurr, Drysdale, and Mulford 2005; 
Raihani 2008). School leadership is an important cornerstone of many governments' economic growth plans, see for example 'School leadership in Asia Pacific: identifying challenges and formulating a research agenda' (Hallinger and Walker 2011); and 'Developing a knowledge base for educational leadership and management in East Asia' (Hallinger 2011). Therefore, school leadership has become an important area of research, and this has been mirrored by increased policy activity in schools (Mertkan 2011, 79); for recent developments see, for example: 'Conceptual and methodological issues in studying school leadership effects as a reciprocal process' (Hallinger and Heck 2011).

Siegrist (1999) argues that "If leadership is vital to schools, preparation of those leaders is very serious business indeed, and graduate programs must move beyond the training of efficient managers, to the preparation of visionary, moral, and transformational leaders." This argument is responded to by Leithwood et al. (2010) in Thomas and Kearney $(2010,10)$ who state that, to date, they have not found a single case of a school improving its student achievement record in the absence of talented and effective leadership.

Although there is much discussion in the educational literature, both supportive and critical, about transformational orientations to leadership, empirical evidence about its effects in school contexts is limited (Leithwood and Jantzi 2006, 204). In particular, there are few studies of school leadership in an Asian context (Raihani 2008; Wong and Wong 2005), and still fewer in an Indonesian school context.

\section{Leadership styles and decision-making styles}

In this paper we largely use the definitions of leadership styles used by Bass (1997). In terms of decision-making styles we largely use definitions by Scott and Bruce (1995a) and the associated website that updates the critiques received since 1995. We use five decision-making styles: rational, dependent, intuitive, spontaneous and avoidant.

We are specifically interested in the following two aspects of the literature: First: our approach to studying leadership is that of measuring transformational, transactional and laissez-faire leadership styles (Bass 1997; Northouse 2007) using Multifactor Leadership Questionnaire (MLQ) 5X-Short (Bass and Avolio 2004). These three leadership styles tend to be related to particular decision-making styles (Tatum et al. 2003, 1012).

A priori we would expect our findings to support Bass' $(1985,1999)$ augmentation effect theory and Judge and Piccolo's $(2004,755)$ findings. Thus to remain effective, leaders need to become more transactional and transformational, but leaders need to avoid laissez-faire leadership style. Bass (1999) asserts that transformational leadership adds to the effectiveness of transactional leadership. Transformational leadership fosters autonomy and challenging work and has become increasingly important to followers' job satisfaction. In contrast, laissez-faire leadership is strongly associated with followers' dissatisfaction, conflict and ineffectiveness. Judge and Piccolo's $(2004,755)$ findings were that transformational leadership did add beyond the effect of just transactional leadership. We would also expect that our findings also support Bass' view that transformational leadership and 
transactional leadership are different but they are not mutually exclusive (Judge and Piccolo 2004).

Studies examining the relationship between transformational leadership style and transactional leadership style appear to result in consistent findings - a significant and positive relationship. Conversely, these two leadership styles tend to have negative relationships with laissez-faire leadership style, which is actually a non-leadership style.

Second: our approach to measuring decision-making styles is that of using the General Decision-Making Style (GDMS) questionnaire developed by Scott and Bruce (1995b). The model consists of five different styles of decision-making: rational, dependent, intuitive, spontaneous and avoidant. Transformational leaders are associated with a more comprehensive (rational) decision-making style, while transactional and/or laissez-faire leaders are associated with a less comprehensive decision-making style (Tatum et al. 2003, 1007).

Leadership styles are related to decision-making styles, as reported by Kao and Kao (2007) who surveyed executives at Taiwanese investment companies in Shanghai, China. This was also found by Tatum et al. (2003) who argue different leadership styles can be primarily associated with different decision-making styles. This led Tatum et al. (2003) to question whether transformational, transactional or laissez-faire leaders practise different decision-making styles. The decision-making styles of leaders vary with the amount of information they have, the number of choices they consider, and the sources of input they have. It is reasonable that prior to making a decision, transformational leaders use a comprehensive or rational decision-making style; they consider more information and more alternatives and listen to more people. In contrast, transactional leaders tend to use limited information and fewer alternatives, and laissez-faire leaders try to avoid decisionmaking (Tatum et al. 2003, 1007). Finally, Tatum et al. $(2003,1012)$ contend that transformational, transactional and laissez-faire leadership styles tend to be related to particular decision-making styles. Similarly, using a sample of 98 officers of a large manufacturing organisation in India, Tambe and Krishnan (2000) found a positive relationship between transformational leadership and rational decision-making style, and a negative relationship between transformational leadership and avoidant decision-making style, while avoidant decision-making style moderated the relationship between transformational leadership and rational decision-making style.

A priori we would expect our findings to support the literature; in particular, that rational decision-makers tend to approach rather than avoid problems; that rational and avoidant decision-making styles are negatively correlated; and that avoidant decision-making style is characterised as relatively passive and as an attempt to avoid decision-making (Scott and Bruce 1995b). Thunholm (2004) found both that the five different styles were not mutually exclusive and that the pattern of their interrelationships corresponded to the findings reported by Scott and Bruce (1995b). We would also expect that our findings are relatively consistent with Thunholm's (2008) research that used a sample of 23 male Swedish Army majors to make decisions in two different military situations. He found that the five decisionmaking styles were not mutually exclusive, and individuals did not rely on a single decision-making style. We would expect that overall our findings are similar. In particular, we would expect to find that rational decision-making style has a positive relationship with dependent decision-making style and has negative relationships with the other three decision-making styles; that is, that our findingswould be 
consistent with those of prior studies (Baiocco, Laghi, and D'Alessio 2008; Gambetti et al. 2008; Scott and Bruce 1995b; Spicer and Sadler-Smith 2005; Thunholm 2004, 2009).

We would expect that what decision-making style a leader displays depends on certain contextual variables. For example, when transformational leaders need to make a comprehensive decision by involving others to obtain information, they tend to use rational decision-making style. In contrast, leaders with transactional and laissez-faire leadership styles tend to produce a less comprehensive decision; thus, such leaders are likely to exhibit spontaneous and even avoidant decision-making styles.

We would also expect that leadership styles are associated with decisionmaking styles. In particular, that analyses of the relationships of transformational leadership style with rational decision-making style and avoidant decision-making style would result in findings consistent with previous research - a significant and positive relationship between transformational leadership style and rational decisionmaking style, but a significant and negative relationship between transformational leadership style and avoidant decision-making style. However, evidence of other relationships between leadership styles and decision-making styles is hard to find in the literature.

In certain conditions, a manager would sometimes be expected to make an intuitive decision (DuBrin, Ireland, and Williams 1989). An intuitive decision is a decision made according to intuition or gut feeling with limited information to reach a decision quickly; it is an unconscious process based on experience. Although the rational decision-making style might be more desirable to analyse a problem rationally, the intuitive decision is also appropriate to face situations quickly. A manager would tend to put greater weight on the intuitive decision than on analytic reasoning when the problems become more complicated (Yang 2003).

In general, there are significant relationships between leadership styles and decision-making styles. However, most of the available studies have been conducted in non-school contexts or in a non-Indonesian school context. Thus studies of these relationships, in this paper, will make an important contribution to the literature and to the development of the Indonesian school system.

\section{The Indonesian context}

Indonesia, like most countries, has a significant historical, geographical and sociological context. Our research into school leadership is deeply embedded in this context. The Indonesian school system has been undergoing significant change since 2002 towards school-based management with mandatory devolution of authority and of power to school-level decision makers structured as School Councils. For recent papers see for example Bandur (2012). However, we have had to leave the wider Indonesian context for another paper and focus instead on one part of our research. 


\section{Methods}

\section{Sample}

The data were collected from a sample of principals and teachers in Lampung Province, Indonesia. A three-stage sampling process was used to randomly select prospective participants. First, geographic districts (primary units) - six geographic districts out of 14 districts (Bandar Lampung, Lampung Tengah, Lampung Selatan, Pesawaran, Pringsewu and Tanggamus) were selected. Second, schools (secondary units) - 37 schools, out of 623 public junior secondary schools in Lampung Province (Kemdiknas 2009a), were selected in the six geographic districts. Finally, participants (tertiary units) - a sample of 518 teachers, out of 11,401 teachers (Kemdiknas 2009b), was chosen from the selected schools. This sample size is greater than the recommended sample size, based on 95\% confidence level (Gray 2004, 218).

\section{Instruments}

Three questionnaires were used for this paper. There are three important aspects related to these questionnaires: first, the validity and the reliability of the questionnaires; second, their suitability for use in the Indonesian context, because the questionnaires are mainly of US origin; and third, what this study will generate in terms of new findings.

Three questionnaires were used in this study: one demographic questionnaire and two standardised questionnaires: Multifactor Leadership Questionnaire (MLQ) Form 5X-Short and the General Decision-Making Style (GDMS) instrument. The demographic questionnaire was developed specifically for this study, and is used to describe participants' demographics: gender, marital status, teacher certification, school location and tenure with current principal.

MLQ Form 5X-Short is the new version of an earlier MLQ developed by Bass $(1985,1995)$ based on previous research and revised in response to criticisms. It was used to describe teacher-perceived leadership styles and teacher-perceived decision-making styles. It is the most widely used instrument to assess transformational and transactional leadership styles. The MLQ Form 5X-Short consists of 45 items - 36 items represent nine leadership factors, originally six factors (i.e. each leadership scale comprises four items), and nine items measure three leadership outcome scales. In particular, transformational leadership comprises five factors: idealised influence (attributes), idealised influence (behaviour), and inspirational motivation - these three factors previously labelled charisma intellectual stimulation, and individualised consideration. Transactional leadership comprises three factors: contingent reward, management-by-exception active, and management-by-exception passive - these last two factors previously labelled management-by-exception - and one non-transactional laissez-faire leadership factor. The MLQ Form 5X-Short is evaluated on a five-point Likert scale that ranges from 0 to 4. Participants' choices associated with these scales are: $0=$ not at all, $1=$ once in a while, $2=$ sometimes, 3 = fairly often, and $4=$ frequently, if not always (Bass and Avolio 2004). The MLQ Form 5X-Short has well-established validity and 
reliability. In particular, reliabilities for the total items and for each leadership factor scale ranged from 0.74 to 0.94 . All the reliabilities of the scales were generally high, exceeding standard cut-offs for internal consistency recommended in the literature (Bass and Avolio 2004, 48).

The GDMS instrument was used to describe teacher-perceived leadership styles and teacher-perceived decision-making styles (Scott and Bruce 1995b). This instrument comprises five decision-making styles: rational, dependent, intuitive, spontaneous and avoidant, with five items identified for each style and measured on a five-point Likert scale - from "strongly disagree" to "strongly agree". Experience has shown consistent findings and reported validity and reliability of the GDMS instrument. Consistency was found in that the five different styles are not mutually exclusive and the pattern of their interrelationships corresponds to the original findings (Scott and Bruce 1995b). Scott and Bruce (1995b) validated the GDMS using a sample of 1943 participants, including content validity, concurrent validity and construct validity. The sample included soldiers, students, engineers and technicians. Scott and Bruce (1995b) reported acceptable internal consistency (alpha ranging from 0.68 to 0.94). More precisely, Scott and Bruce (1995b) reported internal reliabilities for the five scales on their original instrument as having the following ranges in four validation studies: rational $0.77-0.85$, intuitive $0.78-0.84$, avoidant 0.93-0.94, dependent 0.68-0.86 and spontaneous 0.87 (Galotti et al. 2006, 633).

There are other researchers who also reported acceptable validity and reliability of the GDMS instrument. Spicer and Sadler-Smith (2005) supported the construct validity; Baiocco, Laghi, and D'Alessio (2008) supported the convergent validity; and Gambetti et al. (2008) supported the concurrent validity of the GDMS instrument. Thunholm (2004, 2008), Spicer and Sadler-Smith (2005), Baiocco et al. (2008), and Gambetti et al. (2008) reported that the GDMS instrument showed quite adequate internal-consistency reliability. The Cronbach's alpha ranged between 0.65 and 0.86 for rational decision-making style, between 0.72 and 0.81 for intuitive decision-making style, between 0.70 and 0.84 for dependent decision-making style, between 0.77 and 0.84 for spontaneous decision-making style, and between 0.77 and 0.86 for avoidant decision-making style.

However, firstly, these literature sources document different decision-making systems and different management cultures, and are in a non-school context, thus considerable care needs to be exercised in evaluating this very sparse literature, until replication studies can be undertaken. Secondly, the suitability of the instruments for use in the Indonesian context was achieved by careful and best practice, translation from English into Indonesian and back into English by independent academic native speakers, and by careful attention to cultural aspects during data collection by an interviewer who works in the Indonesian school system. Thirdly, while there is considerable literature on the use of the two standardised questionnaires on 'USstyle' or western school systems, there is very little academic literature on how they are applied within the new (since 2002) Indonesian school system. This paper aims to make such a contribution. The questionnaires were designed very carefully to ensure that they were appropriate and that their use was culturally appropriate. Hence, the findings for Indonesia outlined in this paper are in fact comparable with non-Indonesian findings in the literature. 


\section{Other data collected}

Much more data was collected for the whole study than the subset used for this paper. There are data on a number of additional factors that are not used in this paper. For example, gender or length of time working with the current principal (a significant number of respondents had only worked with the principal for a short period of time). These topics could be pursued in further papers. Access to our data is available: please contact the corresponding author.

\section{Data collection procedure}

The three questionnaires were administered to the participants in person, using the hand delivery mode, in their natural setting (schools). The participants were advised that participation was voluntary; they were encouraged to answer as honestly as possible, and were assured that their answers would remain confidential. The questionnaires were completed by 475 teachers ( $92 \%$ response rate) in 36 schools in six districts of Lampung Province, Indonesia.

\section{Data analysis}

Responses to the questionnaires were analysed using Statistical Package for the Social Sciences (SPSS) version 18. The data analysis was carried out as follows. First, the data were coded, entered into SPSS, cleaned for errors, checked for missing data, and rescaled as required. Second, descriptive analysis was used to describe the participants and the variables. Finally, Pearson correlation generated by standard multiple regression analysis was used to address the research questions.

\section{Results and discussion}

\section{Description of the participants}

The 475 sample participants comprised an uneven gender spread (43.6 per cent males and 56.4 per cent females), were mostly married (only 5.1 per cent single and 94.9 per cent married), were nearly equal in teacher certification spread (51.6 per cent certified and 48.4 per cent uncertified), came from two school locations (43.2 per cent urban teachers and 56.8 per cent rural teachers), and had a range of tenure with their current principal (more than half the sampled teachers $(60 \%)$ had been working with their current principal for 1-2 years; there were $26.5 \%$ of the teachers working with their current principal for 3-4 years, 5.5\% working with their current principal for 5-6 years, and $8 \%$ working with their current principal for more than 6 years).

\section{Description of variables}

Table 1 reports mean, standard deviation, skewness and kurtosis used to describe the characteristics of the variables. These variables are: principal leadership styles: transformational (TF), transactional (TA), and laissez-faire (LF); principal decisionmaking styles: rational (Rat), intuitive (Int), dependent (Dep), avoidant (Avo) and spontaneous (Spo); and total teacher job satisfaction (TJS). 
Table 1. Descriptive statistics for variables as perceived by teachers $(n=475)$.

\begin{tabular}{|l|r|r|r|c|}
\hline \multicolumn{1}{|c|}{ Variables1 $^{1}$} & M & SD & Skewness & $\begin{array}{l}\text { Kurtosis } \\
\text { excess }\end{array}$ \\
\hline Transformational & 2.509 & 0.560 & -0.406 & -0.091 \\
\hline Transactional & 2.040 & 0.490 & -0.261 & -0.365 \\
\hline Laissez-faire & 0.819 & 0.674 & 0.642 & -0.423 \\
\hline Rational & 22.145 & 3.176 & -1.267 & 1.233 \\
\hline Intuitive & 13.648 & 5.437 & 0.024 & -1.006 \\
\hline Dependent & 18.842 & 4.146 & -0.479 & -0.294 \\
\hline Avoidant & 10.263 & 4.323 & 0.666 & -0.266 \\
\hline Spontaneous & 13.987 & 4.469 & 0.036 & -0.521 \\
\hline Total teacher job satisfaction & 163.339 & 23.199 & -0.166 & -0.643 \\
\hline
\end{tabular}

Note: ${ }^{1}$ Transformed values of variables.

Mean of transformational leadership style was the highest $(\mathrm{M}=2.51, \mathrm{SD}=$ $0.56)$, followed by mean of transactional leadership style $(\mathrm{M}=2.04, \mathrm{SD}=0.49)$ and laissez-faire leadership style $(\mathrm{M}=0.82, \mathrm{SD}=0.67)$. The scores in the rating ranged from 0 to 4 (Bass and Avolio 2004). Mean of rational decision-making style was the highest $(\mathrm{M}=22.15, \mathrm{SD}=3.18)$, followed by mean of dependent decision-making style $(\mathrm{M}=18.84, \mathrm{SD}=4.15)$, spontaneous decision-making style $(\mathrm{M}=13.99, \mathrm{SD}=$ 4.47), intuitive decision-making style $(\mathrm{M}=13.65, \mathrm{SD}=5.44)$, and avoidant decisionmaking style $(\mathrm{M}=10.26, \mathrm{SD}=4.32)$. The scores in the rating ranged from 5 to 25 (Thunholm 2009). Mean of overall teacher job satisfaction was $163.34(\mathrm{SD}=23.20)$ in the range between 144 and 216 for satisfaction.

These findings suggest: first, according to teachers' perceptions, principals in public junior secondary schools in Lampung Province are more likely to exhibit transformational leadership style, less likely to exhibit transactional leadership style, and hardly likely to exhibit laissez-faire leadership style. Second, despite exhibiting all the five decision-making styles, principals in public junior secondary schools in Lampung Province exhibit rational decision-making style more often than the other four decision-making styles. Finally, the teachers, in general, were satisfied (163 in the range 144-216).

\section{General assumptions}

The general assumptions of a parametric test were checked to confirm accurate results (Field 2009, 132). The assumptions are: continuous measures, random sampling, independence of observations, normal distribution, and homogeneity of variance (Pallant 2007, 203). The first three assumptions were ensured before collecting data. For continuous measures, the data obtained from the standard questionnaires were rescaled from qualitative into continuous variables following Bass and Avolio (2004) for leadership styles and Thunholm (2009) for decisionmaking styles. Random sampling and independence of observations were ensured during the research design phase. Normality of the data was quantitatively assessed using skewness and kurtosis. "Skew should be within the +2 to -2 range when the 
data are normally distributed" (Garson 2010). Table 1 shows that the data were normally distributed because the skewness and kurtosis values are within the +2 to -2 range. Finally, Levene's test was used to test homogeneity for variances (Field 2005, 736). The variances were equal for participants in public secondary schools in Lampung, $F(1,473) \geq 0.05$, NS, for all the variables. The five general assumptions were confirmed.

\section{Overall findings}

The findings in this paper largely confirm previous studies. So at a first glance the contribution to the field is limited. However, this is one of the very few studies undertaken in a developing country and even fewer with an Indonesian context. At the start of the overall project, one of the views was that this methodology, that is largely of US origin, would probably not apply in the Indonesian school system, which has been experiencing significant change since 2002 towards school-based management with mandatory devolution of authority and of power to school-level decision makers (Bandur 2012).

Thus, we suggest a different view of the findings. Given that this paper does largely confirm previous studies, we see it as a significant foundation upon which to build further work in this field to help support the growth of the Indonesian school system into the future.

\section{Findings and discussion regarding the research questions}

Table 2 reports the correlation matrix of the variables. The relationships between the variables are mostly significant: 24 significant relationships and four insignificant relationships.

Table 2. Correlation matrix of variables.

\begin{tabular}{|c|c|c|c|c|c|c|c|c|}
\hline Variable & 1 & 2 & 3 & 4 & 5 & 6 & 7 & 8 \\
\hline 1. TF & 1 & & & & & & & \\
\hline 2. TA & $0.78 * * *$ & 1 & & & & & & \\
\hline 3. LF & $-0.33 * * *$ & $-0.23 * * *$ & 1 & & & & & \\
\hline 4. Rat & $0.44 * * *$ & $0.35 * * *$ & $-0.34 * * *$ & 1 & & & & \\
\hline 5. Int & $-0.22 * * *$ & $-0.13 * *$ & $0.23 * * *$ & $-0.31 * * *$ & 1 & & & \\
\hline 6. Dep & $0.24 * * *$ & $0.24 * * *$ & $-0.11 * *$ & $0.23 * * *$ & -0.01 & 1 & & \\
\hline 7. Avo & $-0.27 * * *$ & $-0.21 * * *$ & $0.30 * * *$ & $-0.34 * * *$ & $0.46 * * *$ & 0.06 & 1 & \\
\hline 8. Spo & 0.03 & $0.09 *$ & $0.08 *$ & $-0.19 * * *$ & $0.35 * * *$ & 0.02 & $0.35 * * *$ & 1 \\
\hline
\end{tabular}




\section{Research question 1: Relationships between principal leadership styles}

These relationships (3 out of 3 ) are highly significant ( $\mathrm{p}<0.001)$ (Alghabban 2004). The strongest (and positive) relationship is between transformational leadership style and transactional leadership style $(\mathrm{r}=0.78, \mathrm{p}<0.001)$. This relationship is much stronger than the (negative) relationship between transformational relationship and laissez-faire leadership style $(r=-0.33, p<0.001)$ as well as between transactional leadership style and laissez-faire leadership style $(r=-0.23, p<0.001)$.

Teachers in public junior secondary schools in Lampung Province are likely to perceive that their principals display transformational leadership style and transactional leadership style but do not display laissez-faire leadership style.

\section{Research question 2: Relationships between principal decision-making styles}

These relationships are mostly significant ( 7 out of 10 ); the insignificant relationships are between dependent decision-making style and three other decisionmaking styles (intuitive, avoidant and spontaneous). Despite being mostly exhibited by principals, rational decision-making style does not provide the strongest relationships with other decision-making styles: intuitive $(r=-0.31, p<0.001)$, avoidant $(\mathrm{r}=-0.34, \mathrm{p}<0.001)$, dependent $(\mathrm{r}=0.23, \mathrm{p}<0.001)$, and spontaneous $(\mathrm{r}=$ $-0.19, \mathrm{p}<0.001$ ). However, the full dataset (not presented in this paper) supports the claim that principals do display rational decision-making. However, intuitive decision-making style provides the strongest and positive relationship with avoidant decision-making style $(r=0.46, p<0.001)$, followed by its relationship with spontaneous decision-making style $(r=0.35, \mathrm{p}<0.001)$ as well as the relationship between avoidant decision-making style and spontaneous decision-making style $(\mathrm{r}=$ $0.35, \mathrm{p}<0.001)$. The weakest, and negative, insignificant relationship is between intuitive decision-making style and dependent decision-making style $(\mathrm{r}=-0.01, \mathrm{p}>$ 0.05). Teachers in public junior secondary schools in Lampung Province are likely to perceive that their principals display more often rational decision-making style than dependent decision-making style and perceive that their principals display less often the other decision-making styles (intuitive decision-making style, avoidant decisionmaking style, and spontaneous decision-making style). In particular, the finding that the relationship between rational decision-making style and avoidant decisionmaking style is negative is expected, but that this relationship is not the strongest is unexpected because these two decision-making styles are very different.

\section{Research question 3: Relationships between principal leadership styles and principal decision-making styles}

These relationships are mostly significant (14 out of 15); the insignificant relationship is between transformational leadership style and spontaneous decisionmaking style. The strongest and positive relationship is between transformational leadership style and rational decision-making style $(\mathrm{r}=0.44, \mathrm{p}<0.001)$. The second strongest and positive relationship is between transactional leadership style and rational decision-making style $(\mathrm{r}=0.35, \mathrm{p}<0.001)$, followed by the negative relationship between laissez-faire leadership style and rational decision-making style $(\mathrm{r}=-0.34, \mathrm{p}<0.001)$. The weakest, but positive, relationship is between 
transformational leadership style and spontaneous decision-making style $(\mathrm{r}=0.03, \mathrm{p}$ $>0.05)$.

Teachers in public junior secondary schools in Lampung Province are likely to prefer their principals to exhibit more often transformational leadership style and rational decision-making style, but this is closely followed by their preference for transactional leadership style and rational decision-making style.

The findings of this paper suggest that the teachers perceive that principals exhibit various leadership styles and decision-making styles, and that the relationships between principal leadership styles and principal decision-making styles are mostly significant. However, due to the lack of studies rather than because the findings from this study are in error, there is a lack of corroborating evidence about these findings in the literature.

\section{Conceptual limitation of the findings}

This paper is one of several about school leadership in schools in Lampung Province, Indonesia. One significant limitation to the findings in this paper is that, with the benefit of hindsight, and after doing one of the very few studies in Indonesia, some ambiguity remains as to whether the responses in the questionnaires are what respondents prefer and desire or what they have observed and experienced. This could well be the topic of further research.

\section{Conclusions and Implications}

\section{Conclusions}

This paper examines the relationships between school principal leadership styles and principal decision-making styles, using survey data from a sample of 475 teachers in six Lampung school districts. Descriptive statistics and standard multiple regression, using SPSS version 18, were used to analyse the data. Descriptive analysis was employed to describe the participants and the variables. Pearson correlation generated by standard multiple regression analysis (standard and hierarchical) was used to address the three research questions.

This paper identified that teachers perceive that the principals exhibited all three leadership styles and all five decision-making styles, and found that the relationships between these variables were mostly significant. These findings suggest: first, that principals are more likely to exhibit transformational leadership style, less likely to exhibit transactional leadership style, and hardly likely to exhibit laissez-faire leadership style. Transformational leadership style and transactional leadership style tend to produce a positive relationship; in contrast, these two leadership styles and laissez-faire leadership style tend to produce a negative relationship. Secondly, that principals are more likely to exhibit rational decisionmaking style and less likely to exhibit the other four decision-making styles. In general, rational decision-making style tends to have a positive relationship with dependent decision-making style but negative relationships with the other three decision-making styles. Finally, in general, transformational leadership style and transactional leadership style tend to produce a positive relationship with rational 
decision-making style and a negative relationship with avoidant decision-making style. In contrast, laissez-faire leadership style tends to produce a negative relationship with rational decision-making style and a positive relationship with avoidant decision-making style.

\section{Implications}

\section{Theoretical implications}

This paper has made a theoretical contribution to knowledge and to methodology in leadership studies. In leadership studies, this paper is the first to identify school principal leadership styles in an Indonesian school context and examine their relationships with principal decision-making styles. In methodology, this paper is the first to use together the two standard survey instruments (MLQ Form 5X-Short and GDMS) used in leadership studies, in an Indonesian school context. This paper linked two elements (leadership styles and decision-making styles) that have not been connected previously in this context. In so doing, this paper makes explicit how principal leadership styles relate to principal decision-making styles in an Indonesian school context.

\section{Practical and policy implications}

This paper has made both practical and policy contributions to an Indonesian school context. From a practical contribution perspective, findings in this paper suggest that, in the teachers' views, principals should: (1) more often exhibit transformational leadership style (closely followed by transactional leadership style) and rational decision-making style; (2) less often exhibit transactional leadership style, and dependent, intuitive and spontaneous decision-making styles; (3) avoid laissez-faire leadership style and avoidant decision-making style; and (4) be aware that Indonesian schools have the potential to be able to increase the exhibition of transformational leadership style.

From a policy contribution perspective, this paper is the first to present findings that provide an important basis for education offices in Indonesia, particularly Lampung Province, to make educational policies; for example, recommending transformational and transactional leadership training for principals and for teachers. Transformational and transactional leadership training could help principals become more effective school leaders. Such training is important for principals as education is fundamental to the production of high quality human resources; in turn, these human resources can contribute to economic growth and thus the increased wellbeing of Indonesian people.

At a school level, and within the context that the Indonesian school system has been undergoing significant change since 2002 towards school-based management with mandatory devolution, implementation of these recommendations could perhaps be progressed. 
The strengths of this paper include its large sample size, use of two widely accepted and well-validated survey instruments, and high (92\%) response rate. These strengths remain despite the limitations in scope and site. The scope is limited to public junior secondary schools, and the site is limited to Lampung Province (one out of the 33 provinces) in Indonesia. These limitations are acknowledged but they do not detract from the significance of the paper's findings and provide possible avenues for further research. For example: (1) enlarge the scope to be able to generalise the findings to all private and public schools (primary, junior and senior secondary schools) in Lampung Province; and (2) enlarge the site to be able to generalise the findings to all Indonesian provinces. Such further research could help improve school leadership in Indonesia. 


\section{References}

Alghabban, A. 2004. Dictionary of Pharmacovigilance. London: Pharmaceutical Press.

Baiocco, R., F. Laghi, and M. D'Alessio. 2008. "Decision-making Style Among Adolescents: Relationship with Sensation Seeking and Locus of Control." Journal of Adolescence 32 (4): 963-976. http://dx.doi.org.elibrary.jcu.edu.au/10.1016/j.adolescence.2008.08.003

Bandur, A. 2012. "School-based Management Developments: Challenges and Impacts." Journal of Educational Administration 50 (6): 845-873. doi:10.1108/09578231211264711.

Barnett, K., and J. McCormick. 2003. "Vision, Relationships and Teacher Motivation: A Case Study." Journal of Educational Administration 41 (1): 55-73.

Bass, B.M. 1985. Leadership and Performance Beyond Expectation. New York, NY: Free Press.

Bass, B.M. 1995. "Theory of Transformational Leadership Redux." The Leadership Quarterly 6 (4): 463-478.

Bass, B.M. 1997. "Does the Transactional-Transformational Leadership Paradigm Transcend Organizational and National Boundaries?" The American Psychologist 52 (2): 130-139.

Bass, B.M. 1999. "Two Decades of Research and Development in Transformational Leadership.” European Journal of Work and Organizational Psychology 8 (1): 9-32.

Bass, B.M., and B.J. Avolio. 2004. Multifactor Leadership Questionnaire: Manual and Sampler Set. 3rd ed. CA: Mind Garden, Inc.

DuBrin, A.J., R.D. Ireland, and J.C. Williams. 1989. Management and Organization. Ohio: South-Western.

Eberlin, R.J., and B.C. Tatum. 2008. "Making Just Decisions: Organizational Justice, Decision-making, and Leadership." Management Decision 46 (2): 310 329.DOI 10.1108/00251740810854177

Field, A. 2005. Discovering Statistics Using SPSS. London: SAGE Publications.

Field, A. 2009. Discovering Statistics Using SPSS. 3rd ed. London: SAGE Publications, Ltd.

Galotti, K.M., E. Ciner, H.E. Altenbaumer, H.J. Geerts, A. Rupp, and J. Woulfe. 2006. "Decision-making Styles in a Real-life Decision: Choosing a College Major." Personality and Individual Differences 41 (4): 629-639.

Gambetti, E., M. Fabbri, L. Bensi, and L. Tonetti. 2008. "A Contribution to the Italian Validation of the General Decision-making Style Inventory." Personality and Individual Differences 44 (4): 842-852. doi:10.1016/j.paid.2007.10.017

Garson, G.D. 2010, 25 January. "Testing of Assumptions.” Accessed 16 March 2010. http://faculty.chass.ncsu.edu/garson/PA765/ assumpt.htm\#normal

Gray, D.E. 2004. Doing Research in the Real World. London: SAGE Publications.

Gurr, D., L. Drysdale, and B. Mulford. 2005. "Successful Principal Leadership: Australian Case Studies.” Journal of Educational Administration 43 (6): 539_ 551. 
Hallinger, P. 2011. "Developing a Knowledge Base for Educational Leadership and Management in East Asia." School Leadership and Management 31 (4): 305320. doi:10.1080/13632434.2011.606267.

Hallinger, P., and R.H. Heck. 2011. "Conceptual and Methodological Issues in Studying School Leadership Effects as a Reciprocal Process." School Effectiveness and School Improvement: An International Journal of Research, Policy and Practice 22 (2): 149-173. doi:10.1080/09243453.2011.565777.

Hallinger, P., and A.D. Walker. 2011. "School Leadership in Asia Pacific: Identifying Challenges and Formulating a Research Agenda." School Leadership and Management 31 (4): 299-303. doi:10.1080/13632434.2011.606988.

Judge, T.A., and R.F. Piccolo. 2004. "Transformational and Transactional Leadership: A Meta-analytic Test of their Relative Validity." Journal of Applied Psychology 89 (5): 755-768.

Kao, P.-H., and H. Kao. 2007. "Taiwanese Executives' Leadership Styles and their Preferred Decision-making Models Used in Mainland China." Journal of American Academy of Business, Cambridge 10 (2): 71-79.

Kemdiknas. 2009a. Rekap data DIKNAS: Rekap data per propinsi. Accessed 31 August 2009. http://npsn.jardiknas.org/cont/data_statistik/ rekap_diknas.php31/08/2009

Kemdiknas. 2009b. Jumlah kepala sekolah dan guru menurut status kepegawaian dan golongan tiap provinsi. Accessed 29 June 2011. http://www.kemdiknas.go.id/media/213896/index_smp_0809.pdf

Leithwood, K., and D. Jantzi. 2006. "Transformational School Leadership for Largescale Reform: Effects on Students, Teachers, and their Classroom Practices." School Effectiveness and School Improvement 17 (2): 201-227.

Mertkan, S. 2011. 'Tensions in Leadership Development: Head Teachers' Experience in North Cyprus." School Leadership and Management 31 (1): 79-90.

Northouse, P.G. 2007. Leadership: Theory and Practice. 4th ed. Thousand Oaks, CA: Sage Publications.

Pallant, J. 2007. SPSS Survival Manual: A Step by Step Guide to Data Analysis Using SPSS for Windows (Version 15). 3rd ed. NSW: Allen \& Unwin.

Pashiardis, P. 1993. "Group Decision Making: The Role of the Principal." The International Journal of Educational Management 7 (2): 8-11.

Raihani. 2008. "An Indonesian Model of Successful School Leadership.” Journal of Educational Administration 46 (4): 481-496.DOI: $\underline{10.1108 / 09578230810882018}$

Robbins, S., R. Bergman, I. Stagg, and M. Coulter. 2009. Management. 5th ed. NSW: Pearson Prentice Hall.

Sanzo, K.L., W.H. Sherman, and J. Clayton. 2011. "Leadership Practices of Successful Middle School Principals." Journal of Educational Administration 49 (1): 31-45. DOI: $10.1108 / 09578231111102045$

Scott, S.G., and R.A. Bruce. 1995a. Updated. General Decision Making Style (GDMS). Associated undated web site. Accessed 12 September 2012. http://www.sjdm.org/dmidi/General_Decision_Making_Style.html 
Scott, S.G., and R.A. Bruce. 1995b. "Decision-making Style: The Development and Assessment of a New Measure." Educational and Psychological Measurement 55 (5): 818-831. doi:10.1177/0013164495055005017

Siegrist, G. 1999. "Educational Leadership Must Move Beyond Management Training to Visionary and Moral Transformational Leaders." Education 120 (2): 297-303.

Spicer, D.P., and E. Sadler-Smith. 2005. "An Examination of the General Decision Making Style Questionnaire in Two UK Samples.” Journal of Managerial Psychology 20 (1/2): 137-149.

Tambe, A., and V.R. Krishnan. 2000. "Leadership in Decision-making." Indian Management 39 (5): 69-79.

Tatum, B.C., R. Eberlin, C. Kottraba, and T. Bradberry. 2003. "Leadership, Decision Making, and Organizational Justice." Management Decision 41 (10): 10061016.

Teodorović, J. 2011. "Classroom and School Factors Related to Student Achievement: What Works for Students?" School Effectiveness and School Improvement: An International Journal of Research, Policy and Practice 22 (2): 215-236. doi:10.1080/09243453.2011.575650.

Thomas, C., and K. Kearney. 2010. "Effective Principal Support: What Will it Take?" Leadership 40 (2): 8-11.

Thunholm, P. 2004. "Decision-making Style: Habit, Style or Both?” Personality and Individual Differences 36 (4): 931-944.

Thunholm, P. 2008. "Decision-making Styles and Physiological Correlates of Negative Stress: Is There a Relation?' Scandinavian Journal of Psychology 49: 213-219.

Thunholm, P. 2009. "Military Leaders and Followers-Do They Have Different Decision Style?" Scandinavian Journal of Psychology 50: 317-324. DOI: 10.1111/j.1467-9450.2009.00714.x

Verhaeghe, G., J. Vanhoof, M. Valcke, and P. Van Petegem. 2010. "Using School Performance Feedback: Perceptions of Primary School Principals.” School Effectiveness and School Improvement: An International Journal of Research, Policy and Practice 21 (2): 167-188. doi: 10.1080/09243450903396005.

Williams, R. 2006. 'Leadership for School Reform: Do Principal Decision-making Styles Reflect a Collaborative Approach?" Canadian Journal of Educational Administration and Policy 53: 1-22.

Wong, P.-M., and C.-S. Wong. 2005. "Promotion Criteria and Satisfaction of School Teachers in Hong Kong." Educational Management Administration and Leadership 33 (4): 423-447.

Yang, B. 2003. "Political Factors in Decision Making and Implications for HRD." Advances in Developing Human Resources 5 (4): 458-479. 